Volume 2, Issue 3, 2019, Pages 89-97

\title{
Evaluation of biscuits prepared from wheat flour and substituted by different levels of doum (Hyphaene thebaica) flour
}

\author{
Ramadan B. R. ${ }^{a}$, Fathia K. S. ${ }^{\mathrm{b}}$, Hassan Manal A. M. ${ }^{\mathrm{a}}$,Zaka A. A. ${ }^{\text {* }}$ \\ ${ }^{a}$ Food Science and Technology Department, Faculty of Agriculture, Assiut University, 71526 Assiut, Egypt \\ ${ }^{b}$ Agricultural Research Center, Giza, Egypt
}

\begin{abstract}
Doum (Hyphaene thebaica) fruit flour (DFF) was studied in terms of chemical properties as well as technological processing to prepare wheat flour biscuits containing DFF. Chemical composition results showed that DFF possessed low contents of crude protein and it could be considered as a good source of minerals $(\mathrm{Ca}, \mathrm{P}, \mathrm{Mg}, \mathrm{Fe}, \mathrm{Cu})$. The results also indicated that $\mathrm{DFF}$ had very good values in terms of crude fiber, total phenolic content, and flavonoid content. The edible portion of doum fruits (DFF) was used to formulate some functional foods. The organoleptic properties of biscuits containing DFF showed that all the biscuits samples were well accepted by the panelists. Generally, doum fruit flour could be used with wheat flour to prepare biscuit characterized with its good sensorial properties, higher nutritive value and healthy as a good source of fiber, minerals, polyphenolic, and flavonoids compounds.
\end{abstract}

Keywords: biscuits, wheat flour, doum, Hyphaene thebaica. 


\section{Introduction}

Doum (Hyphaene thebaica) is an African palm tree, common in Upper Egypt, originally native to the Nile Valley, bearing an edible fruit which is glubosequandrangular, about $6 \times 5 \mathrm{~cm}$ with a shiny orange-brown to deep chestnut skin (epicarp). The rind (mesocarp) in some palm is inedible but of other it is very palatable, highly aromatic and sweet with a taste like gingerbread hence the English name. When eaten it serves as vermifuges and parasite expellant. The chloroform extract of the fruits improves spermatic count of male rats at low concentration, but decrease it at high concentration (Hetta et al., 2005; Hetta and Yassin, 2006). Doum fruit has nutritional and pharmacologic properties. Doum extracts are being used in the treatment of bilharziasis, haematuria, bleeding especially after childbirth, and as hypolipidemic and hematinic suspension. The tea of doum is popular in Egypt and believed to be good for diabetes. It has been used by Egyptian people as a folk medicine for treatment of hypertension (Hetta et al., 2005; Kamis et al., 2003). Roots of doum were used in treatment of Bilharziasis, while the resin of the tree has demonstrated, diuretic, diaphoretic properties and recommended for tap worm as well as against animal bites. The use of some plants as medicinal plant is due to the presence of flavonoids and saponins. Doum was reported to contain important substances including saponins, tannins, and flavonoids; hence the use of doum, which is rich in flavonoids and saponins, in folk medicine is not surprising (Dosumu et al., 2006;
Waterhouse, 2003). Biscuits are the most popular bakery items consumed nearly by all sections of the society in Egypt. Some of the reasons for such wide popularity are low cost in compared with other processed foods (affordable cost), good nutritional quality and availability in different forms, varied taste and longer shelf-life. Bakery products are sometimes used as a vehicle for incorporation of different nutritionally rich ingredients (Sudha et al., 2007). The objective of this study was to use doum fruit pulp powder as a rich source of fiber and as a functional ingredient in biscuit production, evaluate the effect of substitution of wheat flour or yellow maize flower (free gluten) with doum powder on physical, chemical and sensory characteristics of biscuit.

\section{Materials and methods}

\subsection{Materials}

Dry doum fruit flakes were brought from the Agricultural Research Station, Aswan governorate, Egypt and the biscuit ingredients were brought from local supermarket.

\subsubsection{Preparation of raw materials}

Dry doum fruit flakes were milled in a laboratory mill to obtain the whole flour.

\subsection{Methods}

\subsubsection{Proximate composition analysis}

Proximate analysis was carried out using the standard procedures of the Association of Official Analytical 
Chemists (AOAC, 2000). Moisture content was obtained by heating the fresh samples to a constant weight in a thermostatically controlled oven at $60^{\circ} \mathrm{C}$. Ash content was determined $(2 \mathrm{~g})$ by a muffle furnace at $550^{\circ} \mathrm{C}$. Nitrogen content was determined using the Kjeldhal method and crude protein was calculated by multiplying the percentage nitrogen by 6.25. The crude fat content was determined by soxhlet apparatus using petroleum ether $\left(40-60^{\circ} \mathrm{C}\right)$. The crude fiber content was estimated by consecutive acid and alkali digestion of sample followed by washing, drying, ashing at $600^{\circ} \mathrm{C}$ and calculating the weight of ash free fiber. Total carbohydrate was calculated by difference according to Pellet and Sossy (1970). The caloric value $(\mathrm{Kcal} / 100 \mathrm{~g})$ was determined according to Wilson et al. (1974) and Seleet (1990).

\subsubsection{Determination of total polyphenols}

The total polyphenols content of samples was determined using modified FolinCiocâlteu colorimetric method (Singleton et al., 1999). The samples' extracts ( $25 \mu \mathrm{g}$ each) were dissolved in $80 \%$ methanol and further dilution were performed to obtain readings within the standard curve made with gallic acid. The extracts were oxidized by Folin-Ciocâlteu reagent (120 $\mu \mathrm{l})$ and after 5 minutes, $340 \mu \mathrm{l}$ of $\mathrm{Na}_{2} \mathrm{CO}_{3}$ was added for neutralization. The samples were kept for $90 \mathrm{~min}$ in the dark followed by the reading of the absorbance at 750 $\mathrm{nm}$. The results were expressed as milligram of gallic acid equivalents /100 g sample (mg GAE / 100 g sample).

\subsubsection{Determination of total flavonoids}

The aluminium chloride colorimetric assay was used for flavonoids determination, as described by Marinova et al. (2005). Extraction of flavonoids in the samples $(n=3)$ was achieved by homogenizing $2.0 \mathrm{~g}$ of the sample in 50 $\mathrm{mL}$ distilled water. The mixture was transferred into a rotary shaker for $12 \mathrm{~h}$ to ensure full extraction. Thereafter, the mixture was filtered, and the filtrate (extract) made up to $50 \mathrm{~mL}$. Precisely, 1 $\mathrm{ml}$ of extracts or standard solution of catechin $(20,40,60,80$ and $100 \mathrm{mg} / \mathrm{L})$ was added to test tubes containing $4 \mathrm{ml}$ of redistilled water. To this mixture $0.3 \mathrm{ml}$ of $5 \% \mathrm{NaNO}_{2}$ was added. After $5 \mathrm{~min}, 0.3$ $\mathrm{ml} 10 \% \mathrm{AlCl}_{3}$ was added. Immediately, 2 $\mathrm{ml} 1 \mathrm{M} \mathrm{NaOH}$ was added, and the total volume was made up to $10 \mathrm{ml}$ with redistilled water. The solution was mixed thoroughly and the absorbance of both blank and standard was read at $510 \mathrm{~nm}$ using UV-Visible spectrophotometer Model UV 1601 version 2.40 (Shimadzu). Total flavonoids content was expressed as $\mathrm{mg}$ catechin equivalents (mg catechin /100 g sample D.W).

\subsubsection{Determination of minerals content}

Contents of $\mathrm{Ca}, \mathrm{Mg}, \mathrm{Fe}$ and $\mathrm{Cu}$ in the studied samples were determined by iCAP6200 (ICP-OES) Inductively Coupled Plasma Emission Spectrometry (Isaac and Johnson, 1985). However, P content was determined by spectrophotometer (Jackson, 1967) after wet ashing by method described in AOAC (2000). 


\subsubsection{Processing of biscuit}

Control biscuit dough was prepared according to the formula presented in Table (1). The other biscuit sample were prepared using the same formula except for replacing the wheat flour with 5,10 , 15 and $20 \%$ of whole doum flour. Powdered sugar and corn oil were creamed in Braun Mixer with a flat beater for 2 minutes. Water containing sodium chloride, ammonium bicarbonate and rose oil was added to the cream and mixed for 5 minutes to obtain a homogenous cream. Thereafter flour was added slowly to the above cream and was mixed for 2 minutes to obtain biscuit dough. The biscuit dough was sheeted to a thickness of $3.5 \mathrm{~mm}$, cut using a circular mould (51 $\mathrm{mm}$ dia.), and baked at $205^{\circ} \mathrm{C}$ for $9-10$ minutes. After baking, biscuits cooled to room temperature, packed in polypropylene pouches and sealed (Saba, 1997).

\subsubsection{Sensory evaluation of biscuit}

Biscuit samples in pouches coded with different numbers were presented to the judges from the staff of Food Science and Technology Department, Faculty of Agriculture, Assiut University, Assiut, Egypt.

Table (1): Ingredient contents of biscuit formulas.

\begin{tabular}{|l|c|c|c|c|c|}
\hline \multirow{2}{*}{ Ingredients (g) } & \multicolumn{5}{|c|}{ Biscuit formula } \\
\cline { 2 - 6 } & Control & $5 \%$ & $10 \%$ & $15 \%$ & $20 \%$ \\
\hline Wheat flour & 100.00 & 95.00 & 90.00 & 85.00 & 80.00 \\
\hline Doum flour (whole) & -- & 5.00 & 10.00 & 15.00 & 20.00 \\
\hline Powdered sugar & 25.00 & 25.00 & 25.00 & 25.00 & 25.00 \\
\hline Corn oil & 15.00 & 15.00 & 15.00 & 15.00 & 15.00 \\
\hline Salt & 1.00 & 1.00 & 1.00 & 1.00 & 1.00 \\
\hline Ammonium carbonate & 1.00 & 1.00 & 1.00 & 1.00 & 1.00 \\
\hline Rose oil & 0.01 & 0.01 & 0.01 & 0.01 & 0.01 \\
\hline Water & 20.00 & 20.00 & 20.00 & 20.00 & 20.00 \\
\hline
\end{tabular}

They were asked to rate each sensory attribute by assigning a score for surface colour (10), surface characteristics (10), crumb colour (10), taste (20), texture (20) and mouth feel (10) as described by Sudha et al. (2007).

\subsubsection{Statistical analysis}

The experimental data were subjected to an analysis of variance (ANOVA) for a completely randomized design using a statistical analysis system (SAS, 2000).

\section{Results and Discussion}

\subsection{Raw materials}

Gross chemical composition of wheat flour (72\% extraction) and doum flour (g/100g D.W) are shown in Table (2). Wheat flour (WF) and doum fruit flour (DFF) contained 12.85 and $2.99 \%$ crude protein, 1.57 and 2.69 crude fat, 0.63 and $8.97 \%$ ash, 0.82 and $15.22 \%$ crude fiber, 84.13 and $70.13 \%$ carbohydrates, 12.12 and $8.85 \%$ moisture, respectively. 
Wheat flour had higher levels of protein and carbohydrate content than doum powder. While DFF had higher levels of crude fat, crude fiber and ash content than WF. From the above-mentioned data, it was clear that wheat flour was rich in protein and carbohydrates while poor in fat, fiber and ash content, whereas doum powder was rich in the last three components. These results are nearly in agreement with those obtained by Abd ElLatteef et al. (2001).

Table (2): Gross chemical composition* of wheat flour and doum flour (g/100g D.W except moisture).

\begin{tabular}{|l|c|c|c|c|c|c|c|}
\hline Samples & Moisture & Ash & Crude oil & $\begin{array}{c}\text { Crude } \\
\text { protein }\end{array}$ & $\begin{array}{c}\text { Crude } \\
\text { fiber }\end{array}$ & $\begin{array}{c}\text { Total } \\
\text { carbohydrates }\end{array}$ & $\begin{array}{c}\text { Energy } \\
\text { (Kcal/ 100 g D.W.) }\end{array}$ \\
\hline Wheat flour (72\% extraction) & 12.12 & 0.63 & 1.57 & 12.85 & 0.82 & 84.13 & 402.05 \\
\hline Doum flour (whole) & 8.85 & 8.97 & 2.69 & 2.99 & 15.22 & 70.13 & 316.69 \\
\hline L.S.D 0.05 & 0.1319 & 0.0956 & 0.0378 & 0.0632 & 0.0857 & 0.0354 & 0.0995 \\
\hline
\end{tabular}

${ }^{*}$ Mean of triplicates.

Table (3) indicated that doum fruit powder has higher in total phenolics and total flavonoids content $(4539.97 \mathrm{mg}$ GAE/100 g and $2143.62 \mathrm{mg}$ catechin/100 g D.W) than wheat flour $(1518.49 \mathrm{mg}$ GAE/100 g D.W and $711.69 \mathrm{mg}$ catechin/100 g D.W respectively). These results agree with Abou-Elalla (2009), who mentioned that the aqueous extract of doum fruits showed an antioxidant activity, this is due to the substantial amount of their water soluble phenolic and flavonoids content. Table (4) showed that minerals contents were found in reasonable content as result of differentiation between materials. Doum fruit powder contained the highest levels of $\mathrm{Ca}, \mathrm{P}, \mathrm{Mg}$, $\mathrm{Fe}$ and $\mathrm{Cu}$ comparing wheat flour.

Table (3): Phenolics and flavonoids content of wheat flour and doum flour.

\begin{tabular}{|l|c|c|}
\hline Samples & $\begin{array}{c}\text { Total phenolics } \\
\text { (mg GAE/100 g D.W) }\end{array}$ & $\begin{array}{c}\text { Total flavonoids } \\
\text { (mg catechin/100 g D.W) }\end{array}$ \\
\hline Wheat flour (72\% extraction) & 1518.49 & 711.69 \\
\hline Doum flour (whole) & 4539.97 & 2143.62 \\
\hline L.S.D 0.05 & 0.2182 & 0.9438 \\
\hline
\end{tabular}

Table (4): Mineral content of wheat flour and doum flour (mg/100g D.W).

\begin{tabular}{|l|c|c|c|c|c|}
\hline Samples & $\mathrm{Ca}$ & $\mathrm{P}$ & $\mathrm{Mg}$ & $\mathrm{Fe}$ & $\mathrm{Cu}$ \\
\hline Wheat flour (72\% extraction) & 20.39 & 130.73 & 119.70 & 0.81 & 0.33 \\
\hline Doum flour (whole) & 265.44 & 139.21 & 134.25 & 7.78 & 1.62 \\
\hline L.S.D 0.05 & 0.0513 & 0.0441 & 0.1205 & 0.02 & 0.0262 \\
\hline
\end{tabular}

\subsection{Biscuit samples}

Table (5) showed the chemical composition of wheat flour (WF) biscuits replaced with different levels of doum fruit flour. Data revealed that moisture, ash and crude fiber content of biscuit samples were increased with increasing the DFF replacement levels. However total carbohydrates content was decreased. The increase in ash and crude fiber content of biscuits can be attributed 
to their high content in the replaced doum flour. This clearly indicates that high-quality, nutritionally balanced biscuits can be produced by partial replacement of wheat flour with DFF as a good source of dietary fiber and minerals elements. On the other hand, carbohydrate content was reduced as result of DFF replacement level increasing. These results were in agreement with that obtained by Lokurua (2007).

Table (5): Gross chemical composition* of biscuits made from wheat flour (100\%) replaced with different levels of whole doum flour (g/100g D.W except moisture).

\begin{tabular}{|l|c|c|c|c|c|c|c|}
\hline Samples & Moisture & Ash & $\begin{array}{c}\text { Crude } \\
\text { oil }\end{array}$ & $\begin{array}{c}\text { Crude } \\
\text { protein }\end{array}$ & $\begin{array}{c}\text { Crude } \\
\text { fiber }\end{array}$ & $\begin{array}{c}\text { Total } \\
\text { carbohydrates }\end{array}$ & $\begin{array}{c}\text { Energy } \\
\text { (Kcal/100 g D.W. })\end{array}$ \\
\hline Control WFB & 13.37 & 0.71 & 14.45 & 8.02 & 2.01 & 74.81 & 461.37 \\
\hline $5 \%$ DFB & 13.29 & 0.82 & 14.16 & 7.46 & 2.34 & 75.22 & 458.16 \\
\hline 10\% DFB & 16.65 & 1.43 & 14.48 & 7.86 & 2.87 & 73.06 & 454.00 \\
\hline $15 \%$ DFB & 15.17 & 1.88 & 14.20 & 7.48 & 3.06 & 73.38 & 451.24 \\
\hline 20\% DFB & 15.83 & 2.12 & 14.83 & 7.81 & 3.28 & 71.96 & 452.55 \\
\hline LSD 0.05 & 0.0932 & 0.065 & 0.0535 & 0.0603 & 0.0481 & 0.0726 & 0.1559 \\
\hline
\end{tabular}

${ }^{*}$ Mean of triplicates. WFB $=$ Wheat flour biscuit. $\mathrm{DFB}=$ Doum flour biscuit.

The obtained calorific value of doum biscuits with different substitution levels (varied from 451.24 to $458.16 \mathrm{kcal} / 100 \mathrm{~g}$ ) was significantly $(\mathrm{P}<0.05)$ differ and less than control biscuits $(461.37 \mathrm{k} \mathrm{cal} / 100 \mathrm{~g}$ D.W). It is clear that the doum biscuit contain a high of fiber and low energy, so it is good and healthy. Wheat flour biscuits (control) and substituted doum biscuits were analyzed for total phenolics and flavonoids. Data given in Table (6) indicated that substitution of wheat flour with doum fruit flour caused a significant increase in total phenolics content proportionally with increasing the substitution level. The highest value was noticed at 20\% DF substation (1892.50 mg GAE/100g D.W) compared with the control (1117.76 mg GAE/100g D.W) and the other biscuits samples. Same trend was observed in flavonoids of the produced biscuits. Data revealed that 20\% DF substitution had the highest value (1344.84 mg) compared with wheat flour biscuit (495.30 mg catechin /100 g D.W) and the other biscuit samples.

Table (6): Total phenolics, total flavonoids and mineral composition of biscuit samples.

\begin{tabular}{|l|c|c|c|c|c|c|l|}
\hline Samples & $\begin{array}{c}\text { Total phenolics } \\
\text { (mg GAE/100 g D.W })\end{array}$ & $\begin{array}{c}\text { Total flavonoids } \\
\text { (mg catechin/100 g D.W) }\end{array}$ & $\mathrm{Ca}$ & $\mathrm{P}$ & $\mathrm{Mg}$ & $\mathrm{Fe}$ & $\mathrm{Cu}$ \\
\hline Control WFB & 1117.76 & 495.30 & 33.64 & 162.32 & 127.91 & 12.91 & 0.16 \\
\hline 5\% DFB & 1294.08 & 556.74 & 41.75 & 151.30 & 138.24 & 16.81 & 0.44 \\
\hline 10\% DFB & 1382.24 & 821.22 & 45.37 & 186.01 & 145.43 & 20.95 & 0.30 \\
\hline 15\% DFB & 1676.11 & 1125.78 & 46.37 & 187.29 & 146.55 & 20.97 & 0.36 \\
\hline 20\% DFB & 1892.50 & 1344.84 & 47.64 & 196.10 & 148.78 & 21.64 & 0.38 \\
\hline LSD 0.05 & 0.4778 & 0.0902 & 0.049 & 0.095 & 0.1123 & 0.0271 & 0.1142 \\
\hline
\end{tabular}


The results Table (6) showed that minerals $\mathrm{Ca}$ content in the control biscuit was $33.64 \mathrm{mg} / 100 \mathrm{~g}$, this value increased by increasing DFF substitution (from 5 to $20 \%$ ), which were found to be from 41.75 to $47.64 \% \mathrm{mg} / 100 \mathrm{~g}$, respectively. Data presented in Table (6), also showed that the concentration of $\mathrm{P}$ in control sample (162.32 mg/100 g) was lower than that found in the biscuits' samples contain 10 to $20 \%$ DF (varied from 186.01 to $196.10 \mathrm{mg} / 100 \mathrm{~g}$, respectively). Besides, the level and of $\mathrm{Mg}$ and $\mathrm{Fe}$ was slightly increased in biscuit samples with the replacement of DF up to $20 \%$ of wheat flour. There were significant differences $(P<0.05)$ between all biscuits' samples compared with the control in their Fe and $\mathrm{Mg}$ concentration. Moreover, wheat biscuit (control) recorded significant $(P<0.05)$ lower concentration of $\mathrm{Cu}$ than that found in the biscuit sample with DFF addition from 5 to $20 \%$ of wheat flour (Table 6).

\subsection{Sensory evaluation of biscuits samples}

Sensory characteristics of the studied biscuits as influenced by the replacing doum flour of wheat flour are outlined in Table (7).

Table (7): Sensory evaluation of biscuits samples.

\begin{tabular}{|l|c|c|c|c|c|c|c|}
\hline Sample & $\begin{array}{c}\text { Colour } \\
(10)\end{array}$ & $\begin{array}{c}\text { Surface } \\
\text { character (10) }\end{array}$ & $\begin{array}{c}\text { Crumb } \\
\text { colour (10) }\end{array}$ & $\begin{array}{c}\text { Taste } \\
(20)\end{array}$ & $\begin{array}{c}\text { Texture } \\
(20)\end{array}$ & $\begin{array}{c}\text { Mouth } \\
\text { feel (10) }\end{array}$ & $\begin{array}{c}\text { Total } \\
\text { score (80) }\end{array}$ \\
\hline Control WF & 8.75 & 8.59 & 8.50 & 17.40 & 17.37 & 8.59 & 69.21 \\
\hline WF + DF 5\% & 7.98 & 8.01 & 8.08 & 17.30 & 16.98 & 8.36 & 67.35 \\
\hline WF + DF 10\% & 8.61 & 8.37 & 7.75 & 17.46 & 17.68 & 8.15 & 68.05 \\
\hline WF + DF 15\% & 8.43 & 7.78 & 7.56 & 16.70 & 17.25 & 7.75 & 65.48 \\
\hline WF + DF 20\% & 7.93 & 7.09 & 7.87 & 16.28 & 16.62 & 7.24 & 61.98 \\
\hline LSD 0.05 & 0.0708 & 0.0577 & 0.1081 & 0.1098 & 0.0833 & 0.0614 & 0.09 \\
\hline
\end{tabular}

$\mathrm{WF}=$ wheat flour, $\mathrm{DF}=$ doum flour

Data reveled that all sensory attributes of biscuit sample (contained 5-20\% DF of Wheat flour) were lower than that of WF biscuit (control). However, the studied biscuit samples recorded total sensory score (total acceptability) varied from about $90 \%$ (of $20 \%$ DF) to $98 \%$ (of $10 \%$ DF) comparing with that of the control $(0 \%$ DF). As above-mentioned results, wheat flour could be replaced up to $15 \%$ using doum flour without drastically affecting biscuits quality.

\section{Conclusion}

From the obtained results, it could be concluded that the wheat flour can be replaced by doum flour as a good source of fiber, minerals, and antioxidants up to $15 \%$ at least to produce a good acceptable, sensorial, nutritive, and healthy biscuit. 


\section{References}

Abd El-Latteef, B. M., Zaghloul, M. M. and El-Hofi, A. A. (2001), Physical and biological evaluation of biscuits made by using oils from borga, linseed and sesame seed as sources of omega-3 and omega-6 polyunsaturated fatty acid, Proceedings of the first Conference of Role of Biochemistry in Environment and Agriculture, Cairo, Egypt, pp. 55-72.

Abou-Elalla, F. M. (2009), "Antioxidant and anticancer activities of doum fruit extract (Hyphaen thebaica)", African Journal of pure and Applied Chemistry, Vol. 3, pp. 197-201.

AOAC (2000), Official Methods of Analysis, $17^{\text {th }} \quad$ Edition, The Association of Official Analytical Chemists, Washington, DC, USA.

Dosumu, O. O., Nwosu, F. O., Nwogu, C. D. (2006), "Antimicrobial studies and phytochemical screening of extracts of Hyphaene thebaica (Linn) Mart fruits", International Journal of Tropical Medicine, Vol. 1 No. 4, pp. 186-189.

Hetta, M. H. and Yassin, N. Z. (2006), "Comparative studies on hypocholesterolemic effect of different fractions of Hyphaene thebaica (Doum) in experimental animals", Pharmazie, Vol. 61 No. 3, pp. 230-232.

Hetta, M. H., Yassin, N. Z. and El Shaer,
M. A. (2005), "Effect of Hyphaene thebaica on the spermatogenesis of male rats", Egyptian Medicine J.N.R.C., Vol. 4 No. 3, pp. 35-39.

Isaac, R. A. and Johnson, W. A. (1985), "Elemental analysis of plant tissue by Plasma Emission Spectroscopy: Collaborative study", Journal of the Association of Official Analytical Chemists, Vol. 68 No. 3, pp. 499.

Jackson, M. L. (1967), Soil Chemical Analysis, Printice-Hall of India, Private Limited, New Delhi, India.

Kamis, A. B., Modu, S., Zanna, H. and Oniyangi, T. A. (2003), "Preliminary biochemical and haematological effects of aqueous suspension of pulp of Hyphaene thebaica (L) Mart in rats", Biokemistri, Vol. 13, pp. 1-7.

Marinova, D. Ribarova, F. and Atanassova, M. (2005), Total phenolics and total flavonoids in Bulgarian fruits and vegetables, Journal of the University of Chemical Technology and Metallurgy, Vol. 40 No. 3, pp. 255-260.

Pellet, P. I. and Sossy, S. (1970), Food Composition tables for use in the Middle East, American University of Beirut, Beirut, Lebanon.

Saba, N. H. (1997), Culinary is Science and Art (In Arabic), Dar El-MaarefCairo, Egypt, pp. 685.

SAS (2000), SAS User's Guide, Version 
8.1, Statistical Analysis System (SAS) Institute Inc., Cary, USA.

Seleet, F. L. (1990), Preparation and evaluation of some infantile foods, M.Sc. Thesis, Department of Food Science, Faculty of Agriculture, Cairo University, Cairo, Egypt.

Singleton, V. L., Orthofer, R. and Lamuela-Raventos, R. M. (1999), "Analysis of total phenols and other oxidation substrates and antioxidants by means of Folin-Ciocalteu reagent", Methods in Enzymology, Vol. 299, pp. 152-178.

Sudha, M., Vetrimani R, and Leelavathi K (2007), "Influence of fibre from different cereals on the rheological characteristics of wheat flour dough and on biscuit quality", Food Chemistry, Vol. 100 No. 4, pp. 1365-1370.
Waterhouse, A. (2003), Saponins, a new cholesterol fighter, found in red wine, $226^{\text {th }}$ National Meeting of the American Chemical Society, New York, USA.

Wilson, E. D., Fisher, H. and Fagna, E. (1974), Principles of Nutrition, $3^{\text {rd }}$ Ed., John Wiley and Sons, Inc. New York, London, England.

Lokuruka, M. N. I. (2007), "Amino acids and some minerals in the nut of the Turkana doum palm (Hyphaene coriacea)", African Journal of Food Agriculture Nutrition and Development, Vol. 7 No. 2, pp. 15. 